\title{
Evaluation of Water Quality Parameters in Marshes Zone Southern of Iraq Based on Remote Sensing and GIS Techniques
}

\author{
Hashim Ali Hasab • Hussain A. Jawad • Hayder Dibs • \\ Hussain Musa Hussain (D) - Nadhir Al-Ansari
}

Received: 27 January 2020 / Accepted: 13 March 2020 /Published online: 15 April 2020

(C) The Author(s) 2020

\begin{abstract}
Al-Hawizeh Marsh is considered a major marsh in the south of Iraq with a longitude of $47^{\circ} 32^{\prime \prime}-$ $47^{\circ} 45^{\prime \prime}$ and latitude of $31^{\circ} 30^{\prime \prime}-31^{\circ} 42^{\prime \prime}$, length of $80 \mathrm{~km}$ and width of $30 \mathrm{~km}$, while the depth is from 1.5 to $4 \mathrm{~m}$. It has a significant impact on the ecosystem and provides habitat for several types of living creatures. The surface water and the agricultural lands surrounding this marsh suffered from high level degrees of salinity. In the last decades, radical deterioration of water quality in this marsh happened because of the post-war-related events and several human activities. Landsat- 8 data was
\end{abstract}

H. A. Hasab $(\bowtie)$

Al-Furat Al-Awsat Technical University, Technical Institute of Najaf, Najaf, Iraq

e-mail: hasab.hashim1979@gmail.com

e-mail: hashim@atu.edu.iq

H. A. Jawad

College of Science, Kerbala University, Kerbala, Iraq

e-mail: dr.hussain.gis.rs.geo.mohe@gmail.com

H. Dibs

Water Resources Faculty, Hydraulic Structures Engineering

Department, Al-Qasim Green University, Babel, Iraq

e-mail: Dr.hayderdibs@wrec.uoqasim.edu.iq

H. M. Hussain

Remote Sensing Centre, University of Kufa, Kufa, Iraq

e-mail: hussainm.alshimmary@uokufa.edu.iq

N. Al-Ansari

Department of Civil Environmental and Natural Resources Engineering, Lulea University of Technology, Lulea, Sweden e-mail: nadhir.alansari@1tu.se used to predict and evaluate the spatial variation and map distributions of the salinity, $\mathrm{SO}_{4}$ and $\mathrm{CaCO}_{3}$ within Al-Hawizeh Marsh during the two seasons in the year 2017 based on the development of salinity and minerals mathematical equations. The evaluated values for salinity, $\mathrm{SO}_{4}$ and $\mathrm{CaCO}_{3}$ are found to be minimal in winter and maximum in autumn. The values of correlation coefficient $\left(R^{2}\right)$ between the real data and the equation results for the salinity, $\mathrm{SO}_{4}$ and $\mathrm{CaCO}_{3}$ during the two seasons are $0.95,0.96$ and 0.92 , respectively.

Keywords Remote sensing · Marsh · Mathematical equations $\cdot$ Water quality parameters

\section{Introduction}

Marshes being the provider of habitat for several types of plants, animals and insects often form a transition between the aquatic and terrestrial ecosystems. Prediction of marshes water quality by developing an accurate model and its subsequent remediation of water pollutants is prerequisite for a sustainable development and ecological balance. Presently, many environmental problems such as pollution, frequent earthquake, tsunami, global warming, and ozone hole certainly posed severe threat to humankind and nature (Abdul Jabbar 2010). Literature hinted that some of these environmental crises are man-made; however, the actual reasons still need to be clarified.

A large portion of earth's landscape is covered by marshes so-called wetland, which is one of the most 
important habitats that support more life than any other type of habitat. They are also essential to keep our environment clean. Thus, proper restoration of marshes and effective maintenance of their water quality is mandatory for environmental sustainability and human safety in terms of health and hygiene. Marshes being ubiquitous all over the Earth surface, the landscape of Iraq is not an exception. Actually, a large part of Iraq is covered by marshes where keeping the environmental affability to protect the communities from harsh weather conditions, supporting breeding grounds for commercially valuable fishes and offering recreational opportunities are significant. In the last century, there are several critical environmental problems worldwide which have been raised up such as environmental pollution (Chao et al. 2007; Abdul Jabbar 2010). Controlling the marshes water quality by detecting the presence of heavy metals including mercury $(\mathrm{Hg})$, cadmium $(\mathrm{Cd})$, arsenic (As), chromium (Cr), thallium (Th) and lead $(\mathrm{Pb})$ and subsequently remediating them are essential requirements to preserve such habitat for sustainability. Definitely, clean water is an essential requirement for aquatic life and human survival (Wu et al. 2014).

Categorically, several environmentally destructive development and human nonethical activities such as water pollutions, inadequately discharges of sewage and industrial waste waters, poor agricultural practices and lack of integrated watersheds management created major problems. Consequently, the water quality in rivers, lakes and marshes is severely affected. These indicators posed a serious concern to the ecosystem, water resources degradation, public health risks and watersheds especially prone to water quality problems (Azab 2012). Therefore, the quality of surface water is rapidly deteriorating. This is categorized as point sources involving the discrete flows of polluted water that enters the watersheds through a channel or pipe such as the effluent from a sewage treatment plants. They are often associated with municipalities or industries. Conversely, the non-point sources are usually associated with the widely covered land usage including forest management practices, agricultural cultivation and livestock grazing. Generally, these pollution sources enter watersheds area through groundwater flow, overland flow or flow from small tributaries (Wu et al. 2013).

The surface water quality of watersheds such as marshes, lakes and reservoirs often varies depending on natural of hydrological, biological, chemical, morphological and sedimentation processes. Salinity, heavy metals and pathogens such as parasites, bacteria and viruses being the waste materials are most dangerous environmental pollutants (Azab 2012; Kerekes and Baum 2005; Mather and Koch 2011a, b; Ongley 2000; Ustin 2004; Zacharias and Gianni 2008).

The over-exploitation, political reprisals against the inhabitants and lack of coordinated management caused several problems connecting the Iraqi water quality over the past 15 years. Thus, the primary water resources in Iraq including the marshes are contaminated, in which the marshlands water quality is declined and appeared very much harmful for human consumption. The repeated construction of dams due to acute water storage in Turkey and Syria which is the major reason for water quality deterioration in the Iraqi marshlands needs further clarification. Besides, the domestic industrial pollution and hydroelectric power generation along the Euphrates and Tigris Rivers also declined the marshland water quality in Iraq (Khattab and Merkel 2014; Abdul Jabbar 2010; Nicholson and Clark 2003; Sun et al. 2014; Ustin 2004; Wu et al. 2013, 2014). Despite the necessity, research is seldom carried out to model the Iraqi marshlands water quality for effective remediation of pollutants.

War-related destructive man-made events added extra impulses towards environmental crises, in which the natural water recourses are the greatest victim. The unforgettable Gulf War over the past three decades that majorly deteriorated the Iraqi marsh resources and caused irreparable environmental damage in the Arabian Gulf coastal waters needs to be assessed. During Gulf War, million tons of oil that are spilled in the Arabian Gulf eventually affected the water quality of the rivers, streams, lakes and marshes in Iraq (Schwarte 2003; Ustin 2004). In addition, scantily treated sewage, poor land use practices, industrial wastewaters discharges, excessive use of fertilizers and a lack of integrated watershed management are other factors that impacted the marshland water quality in Iraq (Ustin 2004). Yet, no comprehensive study is made to determine their influence on marshland's water quality declination.

The water resource degradation being threatening to the ecosystems and public health requires special attention in terms of remediation. A mathematical model enclosing all these negative effects such as environmentally destructive development, lack of information regarding water quality, poor public awareness and education on the protection of water resources and rapid deterioration of marshland water quality is far from 
being achieved (Kerekes and Baum 2005; Schwarte 2003; Sun et al. 2014; Ustin 2004; Wu et al. 2013, 2014).

With modernization and rapid industrialization, the ever-increasing water and soil salinity appears detrimental unless overcome. For instance, salinity in the Tigris and Euphrates Rivers near their discharge point at the marsh ranges from 0.5 to 2 parts per thousand (PPT). Thus, $74 \%$ of irrigated land that is suffering from certain degree of salination needs remediation (Wu et al. 2013, 2014). In fact, salinity being the key parameter to understanding the water quality in marshland zones requires accurate measurement methods. Marshland salinity is a vital index for all living creatures including vegetations, species, microorganisms, animals, birds, insects and plants. Thus, salinity monitoring, predicting, modelling and simulation are crucial in the evaluation of ecological resources in Iraqi marshland zones. Marshes are represented as important sources to prove agricultural lands by water. Salinity values in the soil had an increase with high water level and decrease with low water level. That means the correlation coefficient between the salinity and the water level is extrusive relation (Pour and Hashim 2015; Hasaba et al. 2017).

While used GIS and remote sensing techniques as well as geology, geomorphology and DEM to located the lineaments of hydrocarbon prospective areas in a part of Cauvery Basin in India (Prabaharan et al. 2017). The merger between GIS and remote sensing data as Sentinel-2 imagery with the soil erosion models Revised Universal Soil Equation (RUSLE) were as powerful tools to derive two different of NDVI layers, assess human activity process, natural phenomena and mapped with localized the risk of soil erosion estimation in Wadi Yalamlam- Saudi Arabia (Bahrawi 2018). The integrated model with the spatial capabilities of GIS together with spatial and temporal capacities of remote sensing can provide a powerful tool for management and assessment of the surface water quality problems (Ammenberg et al. 2002; Azab 2012). Landsat satellite images and GIS are used to map, monitor, assess and change detection of wetland dynamics of Chennai coast in India during three periods from 1988 to 1996,1996 to 2006 and 2006 to 2016 based on a supervised classification method (Jacintha et al. 2019; Roy et al. 2019), geographic information system, analytical hierarchy process and remote sensing techniques such as Aster level-1 T and Landsat 8 Oil used for sustainable groundwater management by delineate the groundwater zones in area of central India with extreme climate conditions. Developed OC-2 and Morel-3 algorithms and integrated with the remote sensing data as Landsat- 8 images to estimate the concentrations of Chlorophyll-a, $\operatorname{Kd}(490)$ and SST in the northwest of Persian gulf during four seasons of 2014 (Dehmordi et al. 2018).

In this view, it was mentioned that remote sensing is highly useful for monitoring and mapping the water quality on the earth's surface (Ammenberg et al. 2002; Ustin 2004). This study depends on the integration between optical remote sensing data using Landsat- 8 (OLI/TIRS) data with the mathematical equations to monitor, assess and map distribution the salinity, $\mathrm{SO}_{4}$ and $\mathrm{CaCO}_{3}$ in Al-Hawizeh Marsh south of Iraq during the two seasons in 2017.

\section{Methodology}

This section elucidates the general steps describing the adopted methodology of this research. The methodology includes study area, data collection, laboratory measurements and water quality parameter equations as the details illustrated below. The output results of this methodology are represented by water quality parameters as salinity, sulphate and calcium carbonate metals obtained from satellite images during the two seasons.

\subsection{Study Area}

The study area is represented by Al-Hawizeh Marsh. It is located in the south of Iraq with a longitude of $47^{\circ}$ $32^{\prime \prime}-47^{\circ} 45^{\prime \prime}$ and latitude of $31^{\circ} 30^{\prime \prime}-31^{\circ} 42^{\prime \prime}$. It is considered a major marsh of Iraq with a length of $80 \mathrm{~km}$ and width of $30 \mathrm{~km}$, while the depth is from 1.5 to $4 \mathrm{~m}$ (Green 1993; Lowi 1995; Maltby 1994; Nicholson and Clark 2003; Partow 2001;Al-Handal and $\mathrm{Hu} 2015$ ).

\subsection{Data Collection}

The water sampling data are collected from different regions of Al-Hawizeh Marsh surface water during the two seasons of 2017. The sampling stations are positioned by using GPS and numbered from HZ1-HZ30 as illustrated in Fig. 1. 


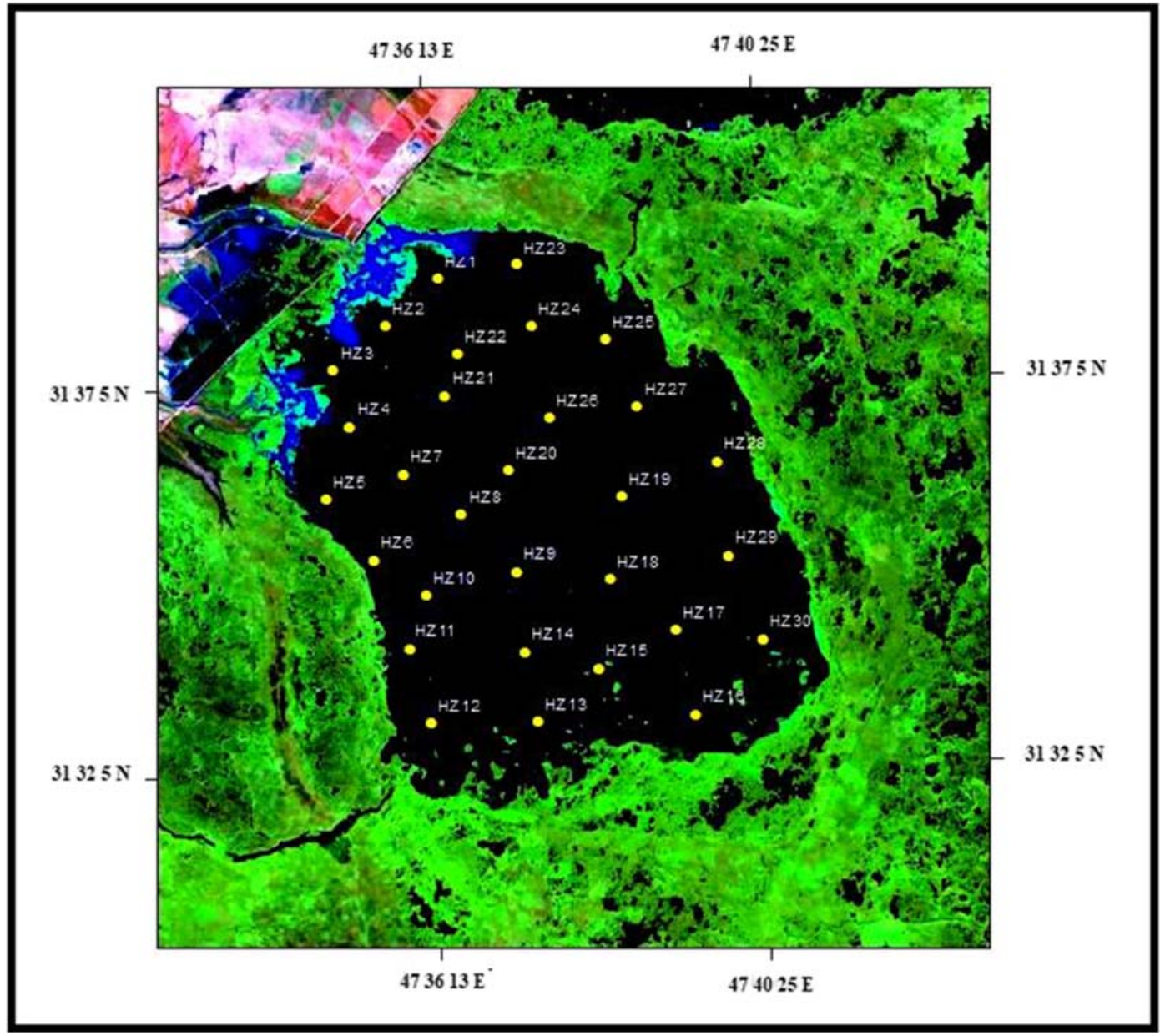

Fig. 1 Study area and sampling stations from satellite image

\subsection{Laboratory Measurements}

The water samples had undergone chemical analyses in the fieldwork lab to measure the water salinity and $\mathrm{SO}_{4}$ and $\mathrm{CaCO}_{3}$ levels. The laboratory results (real data) demonstrated the status of water quality in AlHawizeh Marsh during the two seasons of 2017 as illustrated below.

\subsubsection{Salinity Level}

The concentrations values for salinity by the field measurements during the two seasons are lowest in winter and highest in autumn. The average salinity level during winter and autumn season are 810 and $1865 \mathrm{mg} / \mathrm{l}$, respectively, as shown in Fig. 2.

\subsubsection{Sulphate $\left(\mathrm{SO}_{4}\right)$ Level}

The $\mathrm{SO}_{4}$ concentrations are obtained from the laboratory measurements during the two seasons. The average sulphate contents during winter and autumn season are 129 and $201 \mathrm{mg} / \mathrm{l}$, respectively, which is found to be lowest during winter and highest during autumn as illustrated in Fig. 3.

\subsubsection{Calcium Carbonate $\left(\mathrm{CaCO}_{3}\right)$ Level}

The average $\mathrm{CaCO}_{3}$ concentrations obtained from the laboratory measurements during the two seasons (winter and autumn) are 89 and $165 \mathrm{mg} / \mathrm{l}$, respectively, which is found to be lowest during winter and highest during autumn as presented in Fig. 4. 
Fig. 2 Salinity level in water during the two seasons

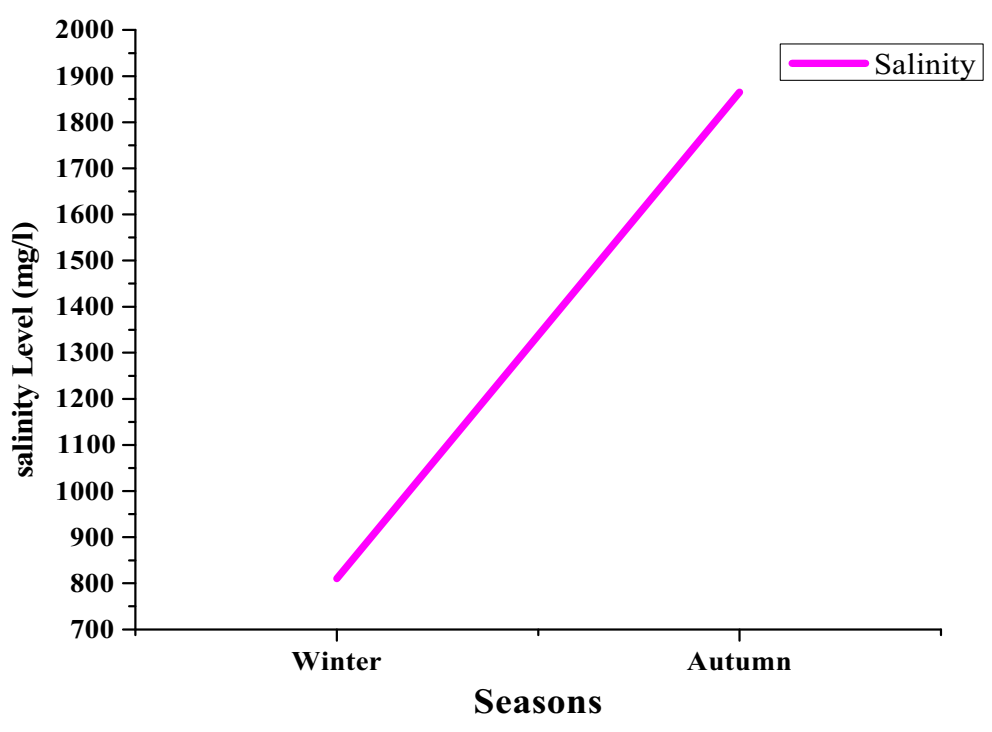

2.4.1 Salinity Values Equation (SVE)

Salinity indices (SI) is based on (B6 and B11) bands of Landsat-8 images as shown in Eq. (1). This equation calculates the indices of the salinity in the water. B6 is a SWIR band having wavelength range of $1.57-1.65 \mu \mathrm{m}$, while B11 is a TIRS2 band having wavelength range of $11.5-12.51 \mu \mathrm{m}$. The output results from this equation act as input data in salinity values equation (SVE) as shown in Eq. (2). SVE calculates the salinity values
Fig. 3 Sulphate level in water during the two seasons

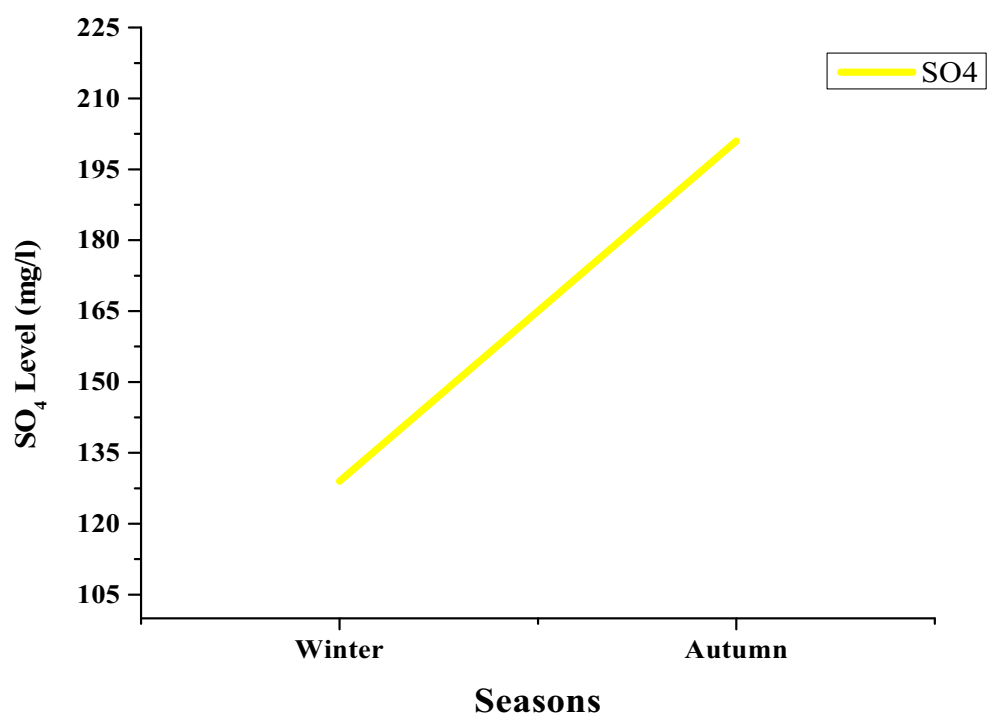


Fig. 4 Sulphate level in water during the two seasons

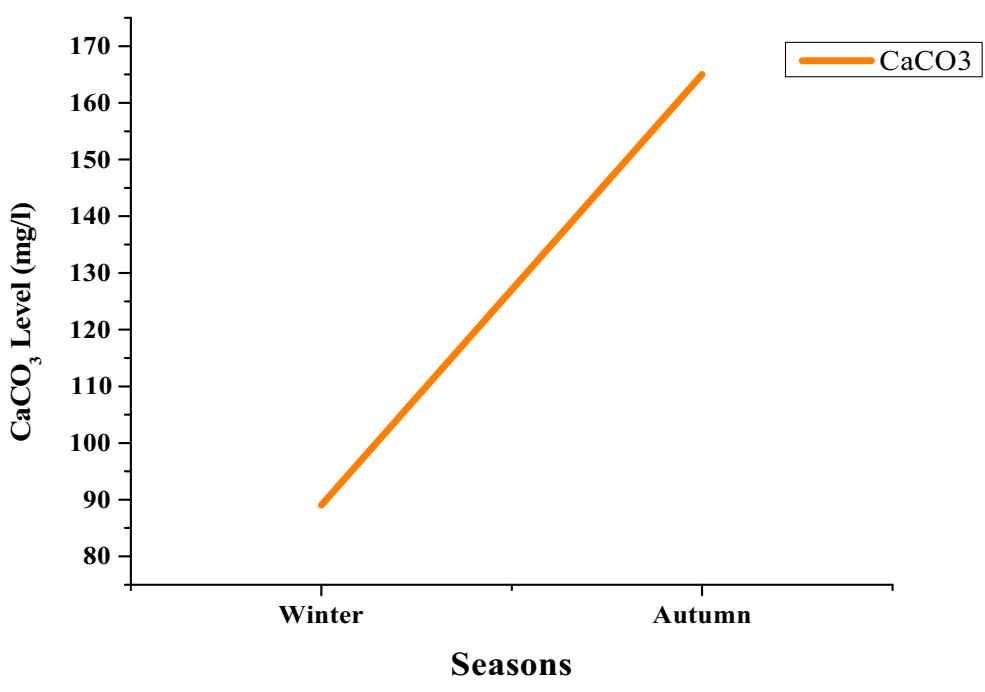

from Landsat- 8 images based on the relationship between the output results of the salinity indices from Landsat- 8 images and the salinity values from ground data.

$\mathrm{SI}=\frac{(\mathrm{B} 11-\mathrm{B} 6)}{(\mathrm{B} 11+\mathrm{B} 6)}=\frac{(\mathrm{TIRS}) 2-(\mathrm{SWIR}) 1}{(\mathrm{TIRS}) 2+(\mathrm{SWIR}) 1}$

$S V E=f \times E X P[g \times S I]+i$

where $f, g$ and $i$ are constants. These constants are dependent on the values of salinity from ground data and indices of salinity from satellite images.

\subsubsection{Minerals Values Equation (MVE)}

These equations are used to calculate the sulphate $\left(\mathrm{SO}_{4}\right)$ and calcium carbonate $\left(\mathrm{CaCO}_{3}\right)$ values from satellite images depending on the correlation between the salinity values from satellite images and the minerals values from ground data. These mineral equations are divided into two types as the following:

Sulphate $\left(\mathrm{SO}_{4}\right)$ Equation This equation was used to calculate sulphate $\left(\mathrm{SO}_{4}\right)$ values from satellite images based on the output results of salinity values equation (SVE) from Landsat-8 images and the ground data of $\mathrm{SO}_{4}$ as shown in Eq. (3) below.
$\left(\mathrm{SO}_{4}\right)=k \times[f \times \operatorname{EXP}(\mathrm{g} \times \mathrm{SVE})+i]^{n}+l$

Calcium Carbonate $\left(\mathrm{CaCO}_{3}\right)$ Equation This equation was used to calculate calcium carbonate $\left(\mathrm{CaCO}_{3}\right)$ values from satellite images based on the output results of salinity values equation (SVE) from Landsat-8 images and the ground data of $\left(\mathrm{CaCO}_{3}\right)$ as shown in Eq. (4) below.

$\left(\mathrm{CaCO}_{3}\right)=\mathrm{k} \times[\mathrm{f} \times \mathrm{EXP}(\mathrm{g} \times \mathrm{SVE})+i]^{n}+l$

where $f, g, i, k$ and $l$ for both of these equations are constants. These constants are dependent on the values of salinity from satellite images and minerals values from ground data. All the previous four steps Eq. (1),(2), (3) and (4) must be repeated again for each season of this study.

Table 1 Min and max values of salinity and minerals from satellite images during the two seasons

\begin{tabular}{|c|c|c|c|c|c|c|}
\hline \multirow[t]{2}{*}{ Seasons } & \multicolumn{2}{|c|}{ Salinity (mg/l) } & \multicolumn{2}{|c|}{$\mathrm{SO}_{4}(\mathrm{mg} / \mathrm{l})$} & \multicolumn{2}{|c|}{$\mathrm{CaCO}_{3}(\mathrm{mg} / \mathrm{l})$} \\
\hline & Min & Max & Min & Max & Min & Max \\
\hline Winter & 253 & 160,807 & 76 & 3987 & 56 & 2077 \\
\hline Autumn & 600 & 3906 & 74 & 375 & 84 & 290 \\
\hline
\end{tabular}


Fig. 5 Salinity level in water during two seasons from satellite images based on SVE equation

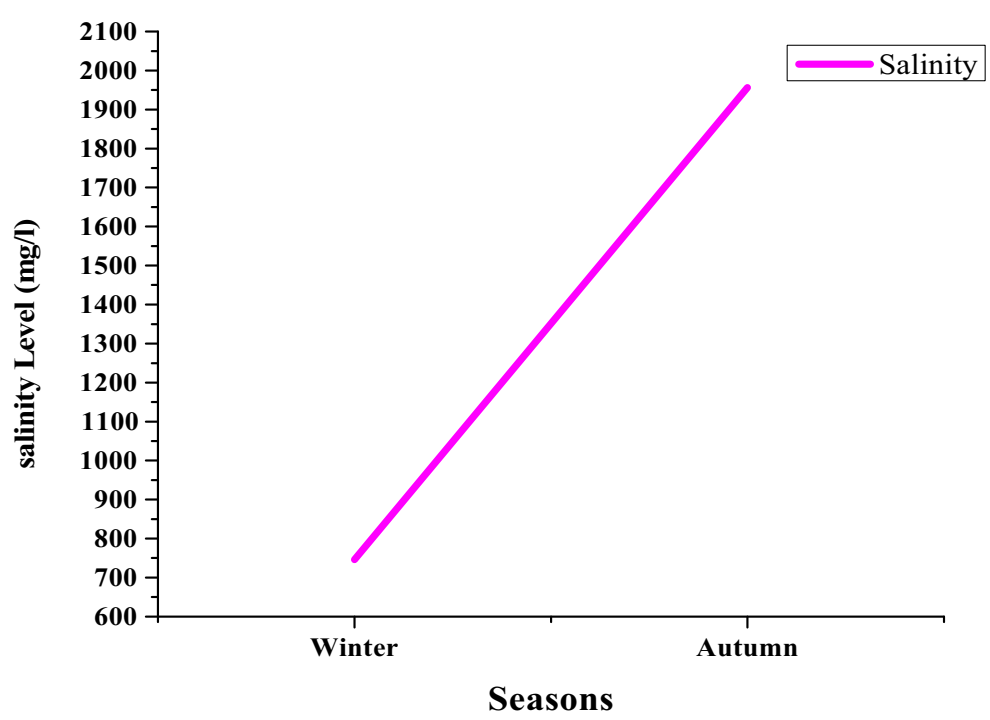

\section{Results and Discussion}

The spatial image distributions for salinity, $\mathrm{SO}_{4}$ and $\mathrm{CaCO}_{3}$ and values are evaluated from Landsat- 8 data based on the integrated between satellite images and previous proposed equations. These values indicated the status of water quality problems in Al-Hawizeh Marsh from the satellite images during the two seasons of 2017. Minimum and maximum values for salinity, sulphate and calcium carbonate from satellite images based on developed equations for salinity and minerals during the two seasons are shown in Table 1.

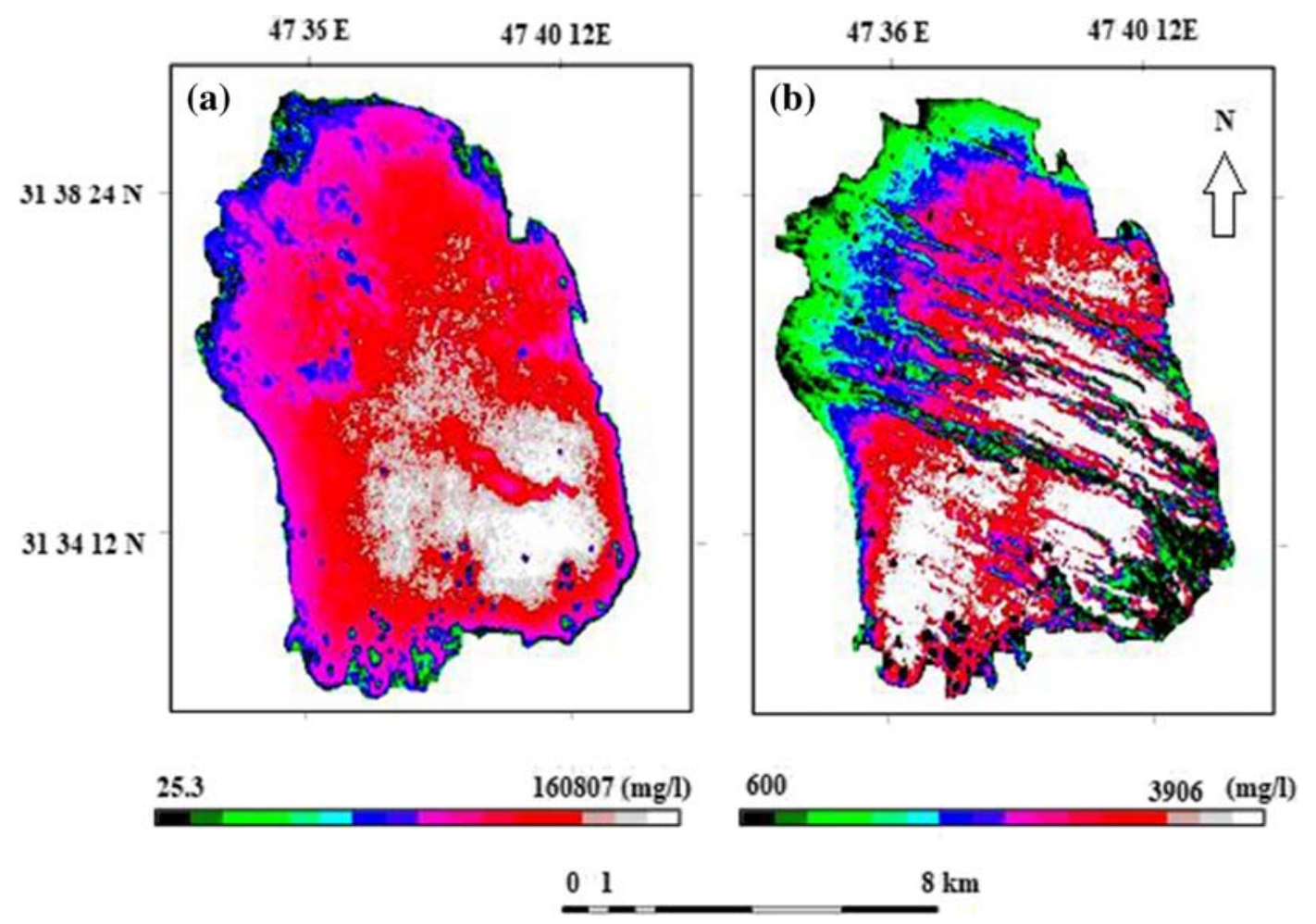

Fig. 6 Spatial distributions of salinity in Al-Hawizeh Marsh during a winter and b autumn 
Fig. 7 Sulphate level in water during two seasons from satellite images based on $\left(\mathrm{SO}_{4}\right)$ equation

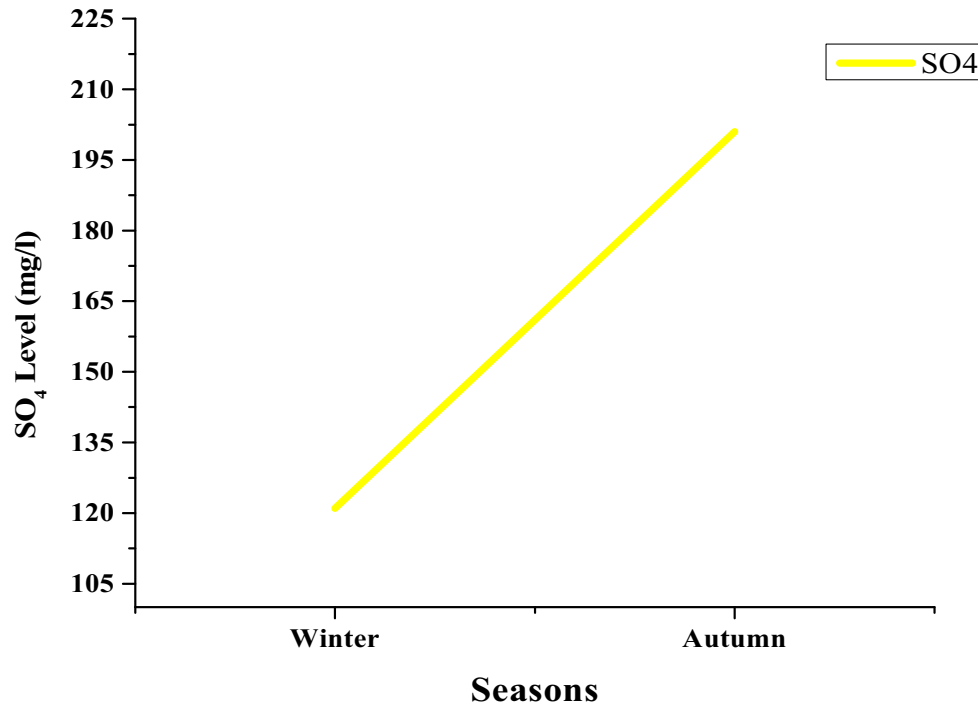

\subsection{Salinity Level}

Figure 5 show the salinity level during the two seasons obtained by using SVE equation. The average salinity level during winter season is $746 \mathrm{mg} / \mathrm{l}$ and in autumn season is
$1956 \mathrm{mg} / \mathrm{l}$. These are observed to be lowest during winter and highest during autumn. This indicated a reduction of the salinity indices in winter and rise in autumn depending on the salinity indices in the water. The salinity indices values are decided by the spectral signatures of Landsat- 8

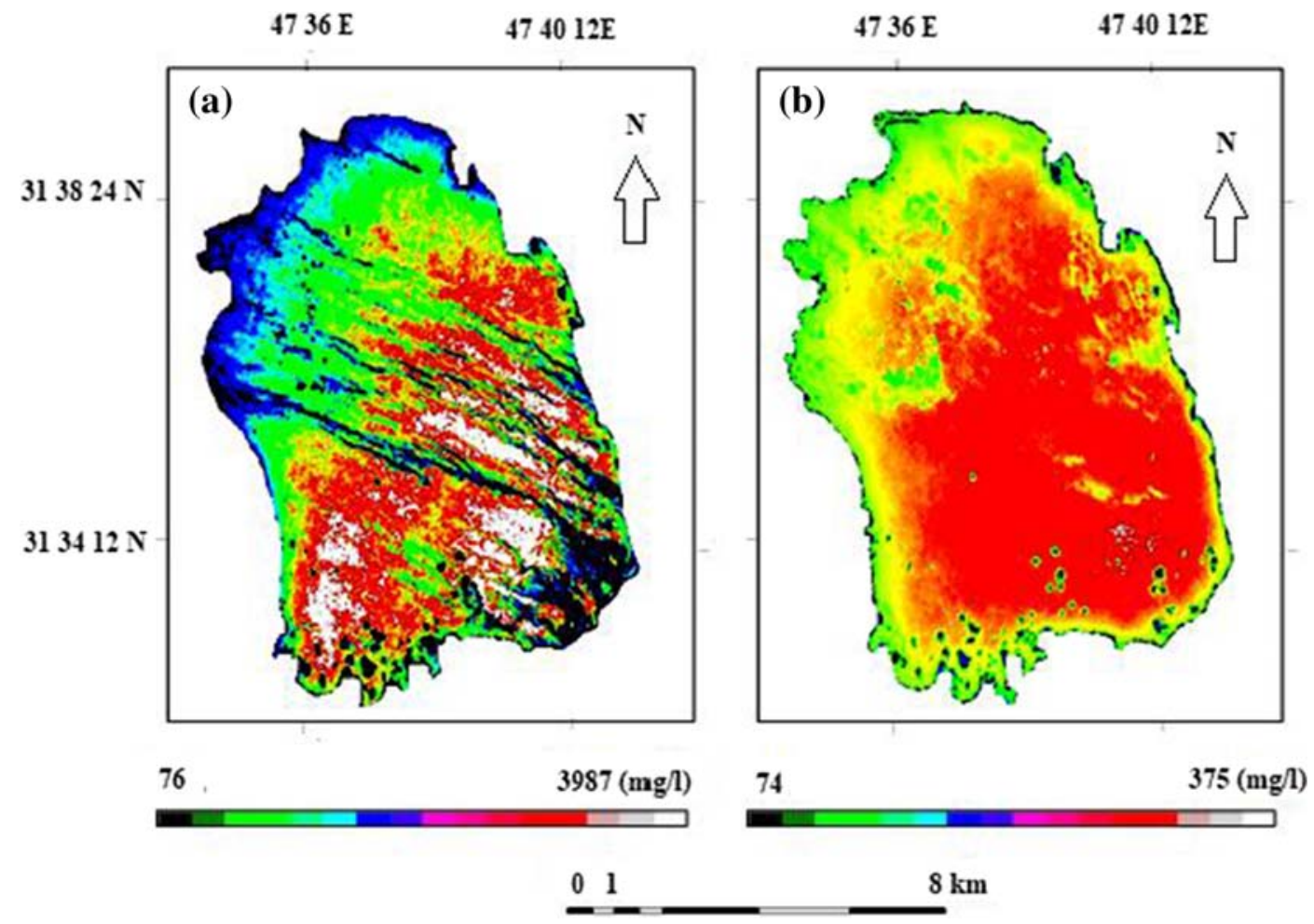

Fig. 8 Spatial distributions of $\mathrm{SO}_{4}$ in Al-Hawizeh Marsh during a winter $\mathbf{b}$ autumn 
Fig. $9 \mathrm{CaCO}_{3}$ level in water during two seasons from satellite images based on $\left(\mathrm{CaCO}_{3}\right)$ equation

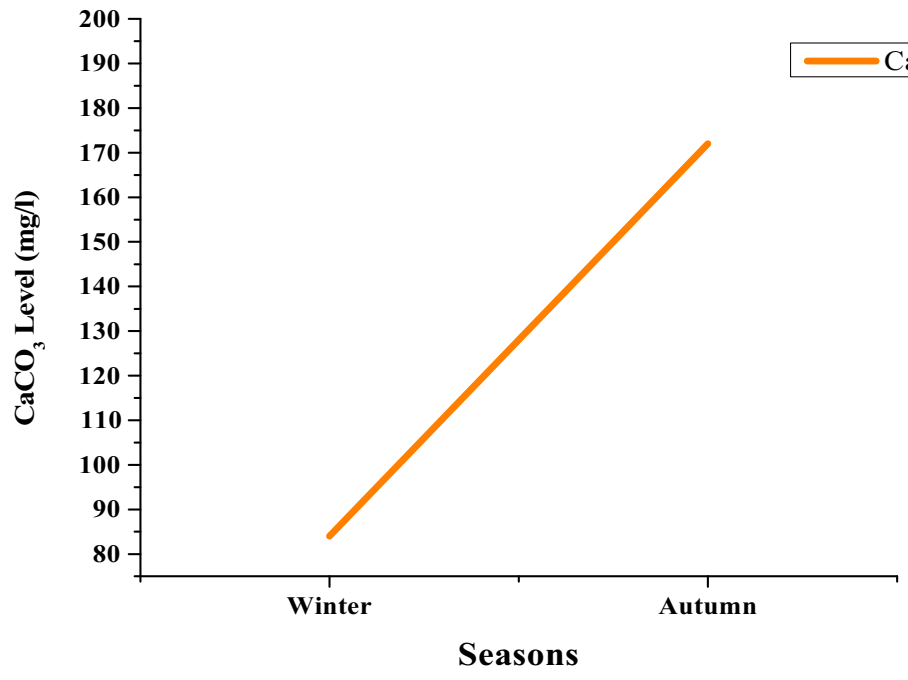

$160,807 \mathrm{mg} / \mathrm{l}$ in the winter while in autumn by ranged between 600 and $3906 \mathrm{mg} / \mathrm{l}$.

\subsection{Determination of Sulphate $\left(\mathrm{SO}_{4}\right)$}

Figure 7 presented $\mathrm{SO}_{4}$ level obtained by using mineral equation of $\mathrm{SO}_{4}$. These results are observed to be lowest

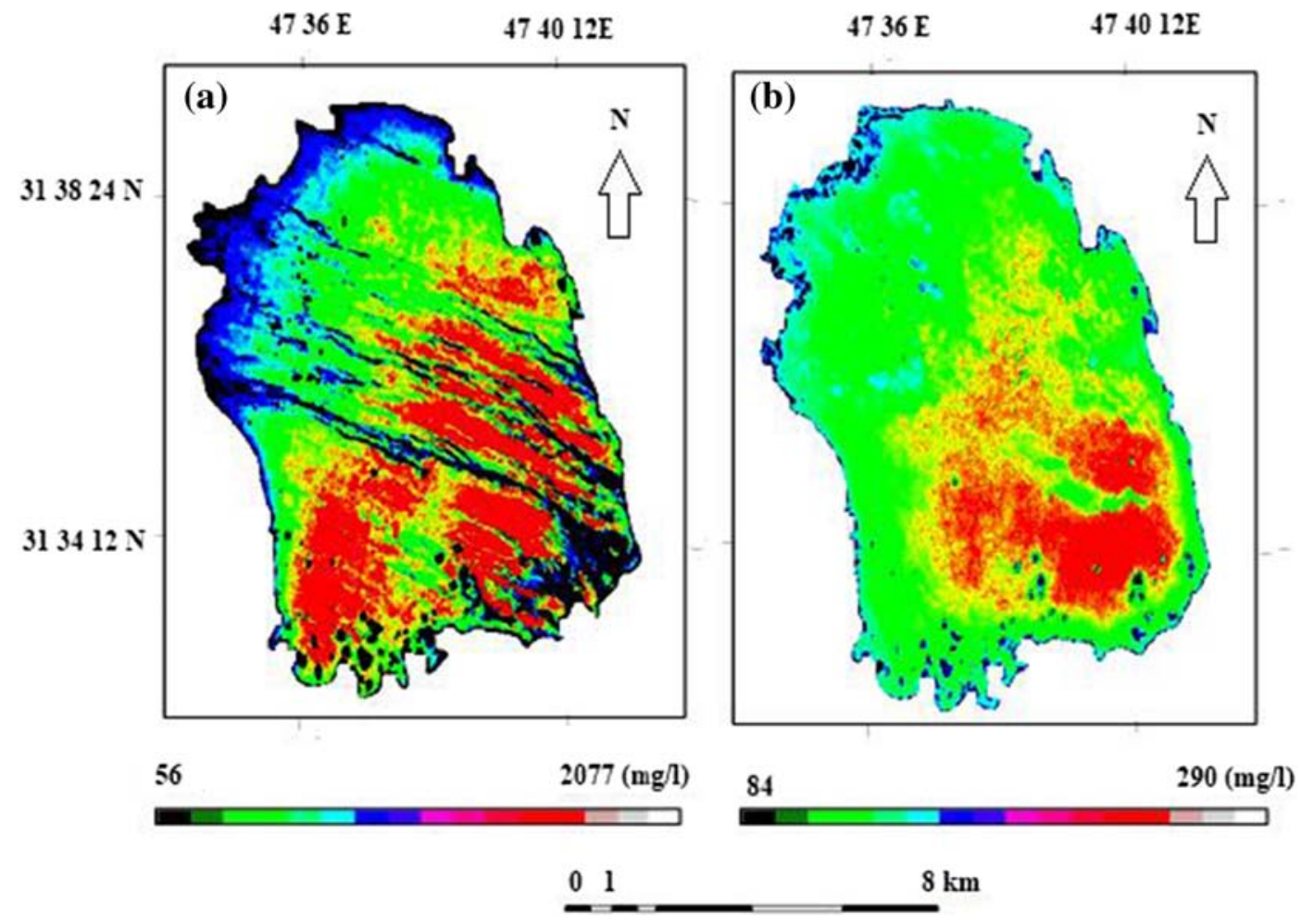

Fig. 10 Spatial distributions of $\mathrm{CaCO}_{3}$ in Al-Hawizeh Marsh during a winter and $\mathbf{b}$ autumn 
during winter and highest during autumn with the average of 121 and $202 \mathrm{mg} / \mathrm{l}$, respectively. These are decided by the salinity values equation (SVE). This indicated a reduction of the salinity indices in winter and rise in autumn. The salinity indices are decided by the spectral signatures of Landsat-8 Short Wave Infrared (SWIR-1) band B6 and Thermal Infrared Sensor (TIRS-2) band B11.The spatial distributions of $\mathrm{SO}_{4}$ in Al-Hawizeh Marsh are obtained by using $\left(\mathrm{SO}_{4}\right)$ equation during the two seasons of year 2017. These are found by the ranged between 76 and $3987 \mathrm{mg} / 1$ in winter and between 74 and $375 \mathrm{mg} / \mathrm{l}$ in autumn as shown in Fig. 8.

\subsection{Determination of $\left(\mathrm{CaCO}_{3}\right)$}

Figure 9 illustrated $\mathrm{CaCO}_{3}$ level obtained by using mineral equation of $\mathrm{CaCO}_{3}$. These results are observed to be lowest during winter and highest during autumn with the average of 84 and $172 \mathrm{mg} / \mathrm{l}$, respectively. These are decided by the salinity values equation (SVE). This indicated a reduction of the salinity indices in winter and rise in autumn. The salinity indices are decided by the spectral signatures of Landsat- 8 Short Wave Infrared (SWIR-1) band B6 and Thermal Infrared Sensor (TIRS-2) band B11. The spatial distributions of $\mathrm{SO}_{4}$ in Al-Hawizeh Marsh are obtained by using (SO4) equation during the two seasons of the year 2017. These are found by the ranged between 56 and $2077 \mathrm{mg} / \mathrm{l}$ in winter and between 84 and $290 \mathrm{mg} / \mathrm{l}$ in autumn as shown in Fig. 10.

\section{Conclusion}

The integration between Landsat- 8 data with the salinity and minerals equations is an important key in the calibration and verification processes of salinity, $\mathrm{SO}_{4}$ and $\mathrm{CaCO}_{3}$ results. The excellent spectral, spatial and temporal capabilities of remote sensing images and the high resolution and suitable bands are allowed in achieving accurate spatial and temporal variations of salinity, $\mathrm{SO}_{4}$ and $\mathrm{CaCO}_{3}$ levels within Al-Hawizeh Marsh. The proposed equations are able to produce results closer to reality. The minimum and maximum salinity levels are 253-160,807 mg/l, with an average of $746 \mathrm{mg} / \mathrm{l}$ in winter while in autumn $600-3906 \mathrm{mg} / \mathrm{l}$, with an average of $1956 \mathrm{mg} / \mathrm{l}$. Sulphate $\left(\mathrm{SO}_{4}\right)$ ranges are between 76 and $3987 \mathrm{mg} / \mathrm{l}$ with an average of $121 \mathrm{mg} / \mathrm{l}$ in winter while in autumn 74-375 mg/l, with an average of $202 \mathrm{mg} / \mathrm{l}$.
$\mathrm{CaCO}_{3}$ level is 56-2077 mg/l with an average of $84 \mathrm{mg} /$ 1 in winter, while $\mathrm{CaCO}_{3}$ level in autumn is $84-29 \mathrm{mg} / \mathrm{l}$, with an average of $172 \mathrm{mg} / \mathrm{l}$. These are observed to be lowest during winter and highest during autumn. This indicated a reduction of the salinity indices in winter and rise in autumn depending on the salinity indices in the water. The values of $R^{2}$, RMSE, SE and probability between the real data and the equation results for salinity during the two seasons are $0.95,89,48$ and $\geq 0.001$ while $0.96,8.7,3.3$ and $\geq 0.001$ for $\mathrm{SO}_{4}$ and then 0.92 , 9,4 and $\leq 0.004$ for $\mathrm{CaCO}_{3}$, respectively.

Funding Information Open access funding provided by Lulea University of Technology.

Open Access This article is licensed under a Creative Commons Attribution 4.0 International License, which permits use, sharing, adaptation, distribution and reproduction in any medium or format, as long as you give appropriate credit to the original author(s) and the source, provide a link to the Creative Commons licence, and indicate if changes were made. The images or other third party material in this article are included in the article's Creative Commons licence, unless indicated otherwise in a credit line to the material. If material is not included in the article's Creative Commons licence and your intended use is not permitted by statutory regulation or exceeds the permitted use, you will need to obtain permission directly from the copyright holder. To view a copy of this licence, visit http://creativecommons.org/licenses/by/4.0/.

\section{References}

Abdul Jabbar, M. F. (2010). Change detections in marsh areas, South Iraq, using remote sensing and gis applications. Iraqi Bulletin of Geology and Mining, 6(2), 17-39.

Al-Handal, A., \& Hu, C. (2015). Modis observations of humaninduced changes in the Mesopotamian marshes in Iraq. Wetlands, 35(1), 31-40.

Ammenberg, P., Flink, P., Lindell, T., Pierson, D., \& Strombeck, N. (2002). Bio-optical modelling combined with remote sensing to assess water quality. International Journal of Remote Sensing, 23(8), 1621-1638.

Azab, A. M. (2012). Integrating GIS, remote sensing and mathematical modelling for surface water quality management in irrigated watersheds (pp. 2-7). CRC Press/Balkema, PO Box 447, 2300 AK Leiden, the Netherlands: Taylor \& Francis Group.

Bahrawi, J. A. (2018). Evaluation of distinctive normalized difference vegetation indices in soil erosion estimation using remote sensing concepts in Wadi Yalamlam, Saudi Arabia. Indian Journal of Geo Marine Sciences, 47(10), 2087-2093.

Chao, X., Jia, Y., Shields, F. D., Wang, S. S., \& Cooper, C. M. (2007). Numerical modeling of water quality and sediment related processes. Ecological Modelling, 201(3), 385-397.

Dehmordi, L. M., Savari, A., Dostshenas, A., Asgari, H. M., \& Abasi, A. (2018). Remote chlorophyll-a, SST and kd490 
retrieval in Northwest Persian gulf using landsat 8 satellite data. Indian Journal of Geo Marine Sciences, 47(10), 148169.

Green, E. A. (1993). Hydropolitics in the Middle East and US policy. NAVAL WAR COLL NEWPORT RI. BMJ (30), 2231.

Hasaba, H. A., Ahmada, A., Marghany, M., \& Ziboon, A. (2015). Landsat TM-8 Data for retrieving salinity in ALHUWAIZAH marsh, south of IRAQ. Jurnal Teknologi, 75(1), 201-206.

Jacintha, T., Rajasree, S. R., Kumar, J. D., \& Sriganesh, J. (2019). Assessment of wetland change dynamics of Chennai coast, Tamil Nadu, India, using satellite remote sensing. Indian Journal of Geo Marine Sciences, 48(8), 1258-1266.

Kerekes, J. P., \& Baum, J. E. (2005). Full-spectrum spectral imaging system analytical model. Geoscience and Remote Sensing, IEEE Transactions on, 43(3), 571-580.

Khattab, M. F., \& Merkel, B. J. (2014). Application of Landsat 5 and Landsat 7 images data for water quality mapping in Mosul Dam Lake, Northern Iraq. Arabian Journal of Geosciences, 7(9), 3557-3573.

Lowi, M. R. (1995). Rivers of conflict, rivers of peace. Journal of international affairs, 49(1), 123-144.

Maltby, E. (Ed.). (1994). An environmental \& ecological study of the Marshlands of Mesopotamia: draft consultative bulletin. AMAR appeal Trust. BMJ (308), 2-23.

Mather, P. M., \& Koch, M. (2011a). Computer processing of remotely-sensed images: an introduction. Hoboken:John Wiley \& Sons, Ltd, Publication

Mather, P. M., \& Koch, M. (2011b). Computer processing of remotely-sensed images: an introduction (pp. 45-50). Hoboken:John Wiley \& Sons

Nicholson, E. \& Clark, P. (2003). Iraqi Marshlands: Politico's Pub.; AMAR International Charitable Foundation

Ongley, E. D. (2000). Water quality management: Design, financing and sustainability considerations-II. Proceedings of the 2000 Invited presentation at the World Bank's Water Week Conference: Towards a strategy for managing water quality management,

Partow, H. (2001). The Mesopotamian Marshlands: demise of an ecosystem. Nairobi (Kenya): Division of Early Warning and Assessment, United Nations Environment Programme. UNEP publication UNEP/DEWA: TR. 01-3

Pour, A. B., \& Hashim, M. (2015). Hydrothermal alteration mapping from Landsat-8 data, Sar Cheshmeh copper mining district, South-Eastern Islamic Republic of Iran. Journal of Taibah University for Science, 9(2), 155-166.

Prabaharan, S., Lakshumanan, C., \& Subramani, T. (2017). Geoscientific study to locate hydrocarbon prospective zones in a part of Cauvery Basin using Remote Sensing and GIS techniques. Indian Journal of Geo Marine Sciences, 46(07), 1447-1453.

Roy, A., Keesari, T., Sinha, U. K., \& Sabarathinam, C. (2019). Delineating groundwater prospect zones in a region with extreme climatic conditions using GIS and remote sensing techniques: A case study from Central India. Journal of Earth System Science, 128(8), 201.

Schwarte, C. (2003). Environmental protection in Islamic law: An overview on potential influences for legal developments in Iraq. Local Environment, 8(5), 567-576.

Sun, D., Qiu, Z., Li, Y., Shi, K., \& Gong, S. (2014). Detection of total phosphorus concentrations of turbid inland waters using a remote sensing method. Water, Air, \& Soil Pollution, 225(5), 1-17.

USGS. (2016). Using the USGS Landsat-8 product. USGS. Science for a changing world, U.S. Department of the Interior, Geological Survey. http://landsat.usgs.gov.

Ustin, S. (2004). Manual of remote sensing: Remote sensing for natural resource management and environmental monitoring. NJ: Wiley Hoboken.

Wu, W., Al-Shafie, W. M., Mhaimeed, A. S., Dardar, B., Ziadat, F. and Payne, W. B. (2013). Multiscale salinity mapping in central and southern Iraq by remote sensing. Proceedings of the 2013 Agro-Geoinformatics (Agro-Geoinformatics), 2013 Second International Conference on, 470-475.

Wu, W., Mhaimeed, A. S., Al-Shafie, W. M., Ziadat, F., Dhehibi, B., Nangia, V., et al. (2014). Mapping soil salinity changes using remote sensing in Central Iraq. Geoderma Regional, 2, 21-31.

Zacharias, I., \& Gianni, A. (2008). Hydrodynamic and dispersion modeling as a tool for restoration of coastal ecosystems. Application to a re-flooded lagoon. Environmental Modelling \& Software, 23(6), 751-767.

Publisher's Note Springer Nature remains neutral with regard to jurisdictional claims in published maps and institutional affiliations. 